\title{
SISTEM PEMBERSIH SENSOR PH OTOMATIS BERBASIS ROBOT ARM DAN STABILIZER PH PADA PROSES TREATED WATER DI PT PETRO JORDAN ABADI
}

\author{
${ }^{1)}$ Devit Nur Cahyono, ${ }^{2)}$ Misbah, \\ Jurusan Teknik Elektro, Fakultas Teknik Universitas Muhammadiyah Gresik \\ J1. Sumatera No 101, Gresik 61121, Jawa Timur \\ E-mail:devitumg@yahoo.com ${ }^{1)}$, misbah.grs@gmail.com ${ }^{2)}$
}

\begin{abstract}
ABSTRAK
PT. Petro Jordan Abadi merupakan pabrik hasil produksi Asam Phospat dengan pengelolahan limbah sendiri, untuk mengolah limbah pabrik dengan beberapa alat instrumentasi $\mathrm{pH}$ meter dan zat kimia antara lain $\mathrm{CaOH}_{2}, \mathrm{NaOH}$, Tawas dan Polimer untuk menetralkan limbah menjadi Treated Water, dimana pompa $\mathrm{NaOH}$ di start-stop lewat control room oleh operator panel yang terkadang terlalu tinggi hingga $\mathrm{pH} 9$ pompa baru distop dan terlalu rendah hingga $\mathrm{pH} 5$ pompa baru di start dan cleaning sensor $\mathrm{pH}$ masih dengan cara manual dilapangan.

Penggunaan system pembersih sensor $\mathrm{pH}$ otomatis dengan robot arm dapat menggerakkan sensor $\mathrm{pH}$ dengan mikrokontroler ATmega 328 lebih sesuai dikarenakan air limbah banyak mengandung phospat dan flour yang dapat menempel pada sensor $\mathrm{pH}$ sehingga sensor $\mathrm{pH}$ akan sering kotor. Proses pembersih sensor $\mathrm{pH}$ otomatis akan bergerak sesuai waktu setiap jam yang diseting yaitu pada saat pergantian shift jam 07.00 pada shift pagi, jam 15.00 pada shift sore dan jam 23.00 pada sift malam.
\end{abstract}

Robot ARM akan mulai bergerak sesuai waktu yang di tentukan dan akan berhenti setelah sensor masuk ke tangki awal dan memonitoring pH pada tangki proses pembuatan treated water. Dengan hasil yang sesuai keinginan perusahaan untuk membersihkan sensor $\mathrm{pH}$ lebih cepat dan tepat dibanding secara manual, dan untuk stabilizer $\mathrm{pH}$ otomatis lebih efektif untuk menstabilkan $\mathrm{pH}$ dibanding secara manual, dengan pembersih dan stabilizer $\mathrm{pH}$ otomatis yang hasilnya alat instrumentasi lebih terawat dan hasil analisa lab lebih bagus dari sebelumnya karena $\mathrm{pH}$ terkontrol dalam proses pembuatan treated water.

Kata Kunci: Mikrokontroler ATmega 328, Robot ARM, Sensor pH, Treated Water.

\section{PENDAHULUAN}

PH air identik dengan proses netralisir limbah yang ada di PT PETRO JORDAN ABADI pada unit Waste Water Treatment Plant. Selama proses Neutralized Water mengalir ke $T K-6651$ tawas akan di pompa selama produk Treated Water berlangsung, selain berfungsi untuk menjernihkan air Neutralized Water, tawas juga mempunyai sifat yang bisa menurunkan $\mathrm{pH}$, maka pompa Soda berfungsi untuk menstabilkan $\mathrm{pH}$ dengan cara start-stop oleh operator Local Control Room di area panel.

Selama proses produk Treated Water sensor $\mathrm{pH} 8$ jam sekali harus di bersihkan karena kandungan phospat dan flour akan menempel pada sensor 
$\mathrm{pH}$ dan menjadi kerak dan kotoran dan akhirnya. Penulis akan membuat sistem pembersih sensor $\mathrm{pH}$ dan stabilizer pompa soda otomatis dengan rumusan masalah "sistem pembersih sensor $P H$ otomatis berbasis robot arm dan stabilizer $P H$ pada proses Treated Water di PT Petro Jordan Abadi". dan diharapkan project ini bisa di aplikasikan di perusahaan tersebut.

\section{TINJAUAN PUSTAKA}

\section{Limbah}

Menurut

Peraturan

Pemerintah Republik Indonesia Nomor 82 tahun 2001, air limbah adalah sisa dari suatu usaha dan atau kegiatan yang berwjud cair. Air limbah dapat berasal dari rumah tangga (domestik) maupun industri (industri). [10]

Tabel 2.1 Standart Kualitas air Treated Water

\begin{tabular}{|l|l|l|l|l|}
\hline & $\begin{array}{l}\text { Aci } \\
\text { dic } \\
\text { Wat } \\
\text { er }\end{array}$ & $\begin{array}{l}\text { Neutral } \\
\text { ized } \\
\text { Water }\end{array}$ & $\begin{array}{l}\text { Treat } \\
\text { ed } \\
\text { Wate } \\
r\end{array}$ & $\begin{array}{l}\text { Satu } \\
\text { an }\end{array}$ \\
\hline \hline $\begin{array}{l}\mathrm{p} \\
\mathrm{H}\end{array}$ & $\begin{array}{l}1- \\
2\end{array}$ & $6-8$ & $6-8$ & \\
\hline $\begin{array}{l}\mathrm{P} \\
\mathrm{O}_{4}\end{array}$ & 467 & 50 & 20 & $\mathrm{ppm}$ \\
\hline $\mathrm{F}$ & $\begin{array}{l}352 \\
5\end{array}$ & 110 & 15 & $\mathrm{ppm}$ \\
\hline $\mathrm{SS}$ & & 200 & 100 & $\mathrm{ppm}$ \\
\hline
\end{tabular}

\section{Sensor keasaman (pH)}

$\mathrm{pH}$ adalah suatu satuan ukur yang menguraikan derajat tingkat kadar keasaman atau kadar alkali dari suatu larutan. Unit $\mathrm{pH}$ diukur pada skala 0 sampai 14 . Istilah $\mathrm{pH}$ berasal dari "p" lambang matematika dari negatif logaritma, dan "H" lambang kimia untuk unsur Hidrogen. Definisi yang formal tentang $\mathrm{pH}$ adalah negatif logaritma dari aktivitas ion Hidrogen. Yang dapat dinyatakan dengan persamaan:

$\mathrm{pH}=-\log [\mathrm{H}+]$

$\mathrm{pH}$ dibentuk dari informasi kuantitatif yang dinyatakan oleh tingkat keasaman atau basa yang berkaitan dengan aktivitas ion Hidrogen. Jika konsentrasi $[\mathrm{H}+]$ lebih besar daripada [OH-], maka material tersebut bersifat asam, yaitu nilai $\mathrm{pH}$ kurang dari 7 Jika konsentrasi [OH-] lebih besar daripada $[\mathrm{H}+]$, maka material tersebut bersifat basa, yaitu dengan nilai $\mathrm{pH}$ lebih dari 7.

\section{Modul pH Value V1.1}

Pada sensor $\mathrm{pH}$ ini terdapat modul $\mathrm{pH}$ value sebagai penguat keluaran tegangan karena jika hanya menggunakan sensor saja maka output yang dihasilkan berupa tegangan yang sangat kecil sehingga sulit untuk dibaca ADC.

Untuk menggunakannya hanya menghubungkan sensor $\mathrm{pH}$ dengan konektor $\mathrm{BNC}$, dan pasang antarmuka PH2.0 ke port input analog dari controller Arduino. Jika pradiprogram, akan mendapatkan nilai $\mathrm{pH}$ dengan mudah. Versi 1.1 didasarkan pada peningkatan Versi 1.0. dengan mengubah chip biayapompa dengan akurasi yang lebih tinggi.

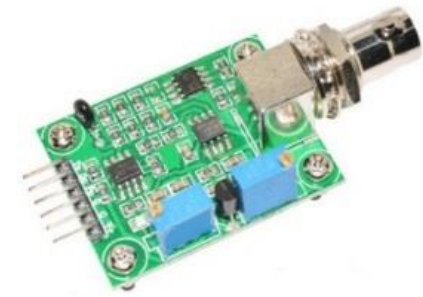

Gambar 2.1 Modul PH value V1.1

Pompa DC 
Pompa adalah suatu alat atau mesin yang digunakan untuk memindahkan cairan dari suatu tempat ke tempat yang lain melalui suatu media perpipaan dengan cara menambahkan energi pada cairan yang dipindahkan dan berlangsung secara terus menerus.

Pompa beroperasi dengan prinsip membuat perbedaan tekanan antara bagian masuk (suction) dengan bagian keluar (discharge). Dengan kata lain, pompa berfungsi mengubah tenaga mekanis dari suatu sumber tenaga (penggerak) menjadi tenaga kinetis (kecepatan), dimana tenaga ini berguna untuk mengalirkan cairan dan mengatasi hambatan yang ada sepanjang pengaliran.[2]

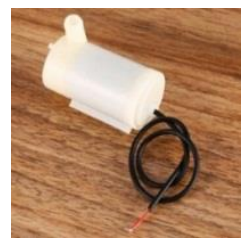

Gambar 2. 2 Pompa Motor DC

\section{Motor servo MG996}

Motor servo adalah sebuah motor DC yang dilengkapi rangkaian kendali dengan system closed feedback yang terintegrasi dalam motor tersebut. Pada motor servo posisi putaran sumbu (axis) dari motor akan diinformasikan kembali ke rangkaian kontrol yang ada di dalam motor servo.

Motor servo disusun dari sebuah motor DC, gearbox, variabel resistor (VR) atau potensiometer dan rangkaian kontrol. Potensiometer berfungsi untuk menentukan batas maksimum putaran sumbu (axis) motor servo. Sedangkan sudut dari sumbu motor servo diatur berdasarkan lebar pulsa yang pada pin kontrol motor servo.

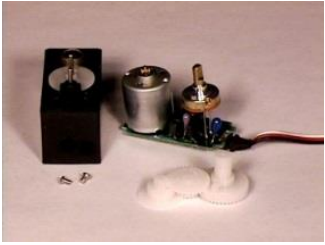

Gambar 2. 3 Konstruksi Motor Servo

Motor servo adalah motor yang mampu bekerja dua arah $(\mathrm{CW}$ dan $\mathrm{CCW}$ ) dimana arah dan sudut pergerakan rotornya dapat dikendalikan dengan memberikan variasi lebar pulsa (duty cycle) sinyal PWM pada bagian pin kontrolnya.

\section{PERENCANAAN PERANCANGAN ALAT}

Berikut ini gambar 3.1 adalah blok diagram perancangan dan pembuatan Alat secara keseluruhan:

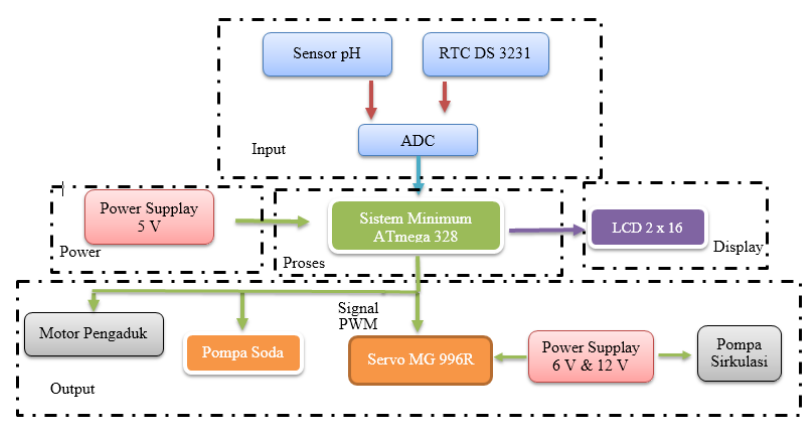

Gambar 3.1 Blok Diagram

Perancangan dan Pembuatan Alat

Pada gambar 3.1 blok diagram diatas dijelaskan, pada kolom input terdapat masukan sensor $\mathrm{pH}$ sebagai indikator pengambil nilai tingkat keasaman air dan Real Time Clock DS 3231 sebagai pengolah waktu sesuai dengan waktu yang ada di Indonesia dengan menentukan jam, tanggal, bulan dan tahun.

Power Supplay 5 volt dengan travo 2 ampere akan membagi arus 1 ampere ke system atmega 328, 2 motor pengaduk dan pompa soda, power suplay 6 volt dan 12 volt 5 ampere akan memberi arus dan tegangan ke motor servo untuk 6 volt 
dan pompa sirkulasi ke 12 volt, saat power masuk motor pengaduk dan pompa sirkulasi langsung start, setelah system minimum mendapat power maka nilai ADC dari sensor $\mathrm{pH}$ dan RTC ds 3231 akan di proses oleh IC ATmega 328.

LCD 6 × 12 akan menampilkan nilai $\mathrm{pH}$ yang masuk dan jam, tanggal, bulan dan tahun yang sudah di seting, pada servo mg 996r robot ARM akan bergerak saat jam yang di seting sudah sesuai yaitu pukul 07.00.00, 15.00.00 dan 23.00.00, kemudian pompa soda akan $O N$ jika pH 6,0 dan berhenti saat $\mathrm{pH} \quad 7.0$ dengan dilengkapi relay untuk memisahkan sumber arus dan tegangan dengan rangkaian system minimum saat pompa berputar.

Skema rangkaian system minimum ATmega 328

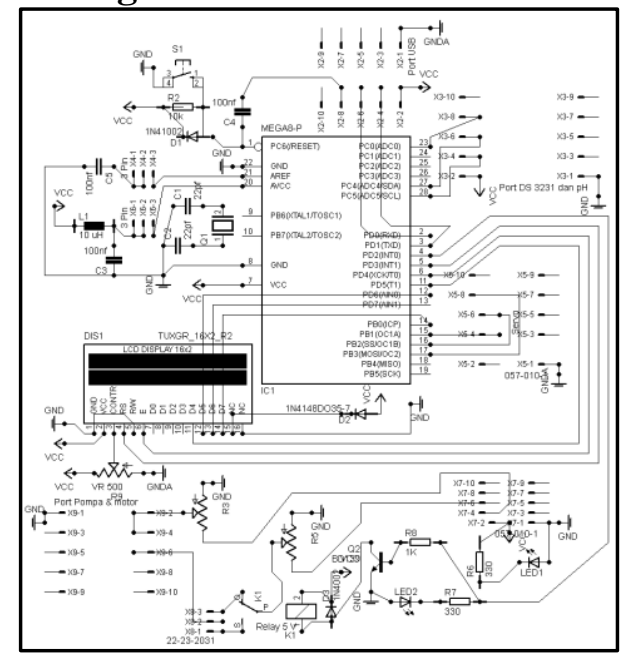

Gambar 3.2 Skema Rangkaian Sistem Minimum ATmega 328

Rangkaian sistem minimum ATmega 328 menggunakan 5 port header AMP 0, port yang pertama digunakan untuk komunikasi pemrograman dengan menggunakan USB serial adapter $\mathrm{CH} 340 \mathrm{G}$ untuk komunikasi download dan upload dari pc ke IC ATmega 328 dengan menggunakan,+- , RX, TX, dan reset dengan tambahan kapasitor 100nf dijalurnya, port yang kedua dihubungkan dengan rangkaian RTC untuk jalur SDA pada pin A4 atmega 328 dan SCL pada pin A5 dan sensor $\mathrm{pH}$ dengan jalur Po ke pin A0 ATmega 328, port yang ketiga dihubungkan dengan servo MG $996 \mathrm{R}$ pada pin 9, 10 dan 11 untuk menggerakkan robot ARM dengan power tersendiri sebesar $6 \mathrm{~V}$, port yang keempat yaitu port power dari masukan power suplay dengan tegangan $5 \mathrm{~V}$ dengan arus maksimal 1A dan port yang terakhir untuk menggerakkan 2 motor pengaduk, dan pompa soda.

Sistem minimum juga dilengkapi dengan relay untuk menjalankan pompa soda dengan power sendiri $5 \mathrm{~V}$ dan LCD untuk menampilkan $\mathrm{pH}$ dan Waktu. Kristal yang digunakan untuk pengoprasian system minimum adalah $16 \mathrm{MHz}$.

Pada pin AVCC di tambah inductor $10 \mu \mathrm{H}$ ke VCC dan Kapasitor 100nf ke Ground dan Aref ( Analog referensi ) di tambah kapasitor 100nf ke Ground. System minimum ATmega 328 disini memilik tugas antara lain :

1. Mengambil data dari sensor $\mathrm{pH}$.

2. Mengambil data dari modul RTC ds 3231 .

3. Menggerakkan 3 servo untuk penggerak robot ARM..

4. Menampilkan data pada LCD $16 \times 2$.

5. Pengatur relay sebagai kontrol pompa soda. 
Perancangan Robot Arm dan
perlengkapannya

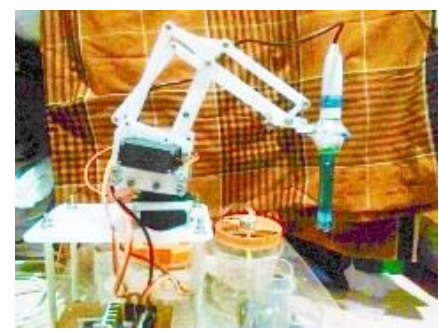

Gambar 3.3 Perancangan Mekanik Robot ARM

Tahap pembuatan robot arm secara mekanik yaitu merakit servo1 pada bagian bawah dengan memasang mur \& baut, memasang motor servo 2 pada akrilik dan dipasang dengan baut \& mur sebelah kanan dan kiri untuk servo 3 kemudian merakit lengan dengan mur $\&$ baut untuk pemegangan sensor $\mathrm{pH}$.

Sedangkan untuk desain lengannya terbuat dari akrilik yang sudah dipesan, sehingga untuk perakitannya hanya memsang dan menggabungkan satu akrilik dan akrilik lainnya menjadi suatu kesatuan menjadi lengan, untuk tempat meletakkan sensor $\mathrm{pH}$ dipasang potongan selang kecil dan direkatkan dengan isolasi untuk menahannya.

Untuk menahan robot menggunakan baut panjang sebanyak 8 potong pada bagian atas 4 dan bawah 4, ditambah dengan akrilik dan papan kayu untuk tempat system minimum dan power supplay 12 Volt 5 Ampere di letakkan bagian bawah sendiri tepat diatas papan kayu.

\section{PENGUJIAN DAN ANALISA ALAT}

Pengujian motor servo menggunakan rangkaian system minimum dilakukan dengan dihubungkan langsung dengan pin 9, 10 dan 11 pada motor servo, kemudian untuk tegangan kerja motor servo membutuhkan power sebesar 6 volt DC sendiri agar motor servo dapat berputar sesuai yang di inginkan.

Dan untuk melakukan pengujian terhadap motor servo diperlukan listing program untuk mengontrol arah putaran motor servo, uji coba selanjutnya akan menggerakan motor servo dengan arah putaran jarum jam sebesar 180 derajat, dan akan kembali pada posisi awal yaitu 0 derajat ketika arah putaran sudah mencapai 180 derajat, proses ini secara terus menerus sampai power supply di matikan.

Tabel uji coba motor servo menggunakan listing program sederhana dan dapat dilihat pada Tabel 4.1 sebagai berikut:

Tabel 4.1 Pengujian Gerakan motor servo saat cleaning sensor $\mathrm{pH}$

\begin{tabular}{|c|c|c|c|c|c|}
\hline \multirow{2}{*}{ Posisi } & \multirow{2}{*}{ Tahap } & Servo Bawah & Servo Kanan & Servo Kiri & \multirow{2}{*}{ Keterangan } \\
\hline & & Sevo 1 & Sevo 2 & Sevo 3 & \\
\hline Posisi Awal & Gerak 1 & $145^{\circ}$ & $80^{\circ}$ & $0^{\circ}$ & Masuk ke tangki \\
\hline Posisi naik 1 & Gerak 2 & $145^{\circ}$ & $20^{\circ}$ & $50^{\circ}$ & Angkat sensor $\mathrm{pH}$ \\
\hline posisi pindah1 & Gerak 3 & $85^{\circ}$ & $20^{\circ}$ & $50^{\circ}$ & Geser / pindah posisi \\
\hline Posisi turun1 & Gerak 4 & $85^{\circ}$ & $80^{\circ}$ & $5^{\circ}$ & Celupkan sensor pH ke HCL \\
\hline \multicolumn{6}{|c|}{ delay 1 menit } \\
\hline Posisi naik2 & Gerak 5 & $85^{\circ}$ & $20^{\circ}$ & $50^{\circ}$ & Angkat sensor $\mathrm{pH}$ \\
\hline posisi pindah2 & Gerak 6 & $104^{\circ}$ & $20^{\circ}$ & $50^{\circ}$ & Geser / pindah posisi \\
\hline Posisi turun2 & Gerak 7 & $104^{\circ}$ & $80^{\circ}$ & $5^{\circ}$ & Celupkan ke pH netral $=7$ \\
\hline \multicolumn{6}{|c|}{ delay 1 menit } \\
\hline Posisi naik3 & Gerak 8 & $104^{\circ}$ & $20^{\circ}$ & $50^{\circ}$ & Angkat Sensor $\mathrm{pH}$ \\
\hline posisi pindah3 & Gerak 9 & $145^{\circ}$ & $20^{\circ}$ & $50^{\circ}$ & Geser / pindah posisi \\
\hline Posisi turun 3 & Gerak 10 & $145^{\circ}$ & $80^{\circ}$ & $50^{\circ}$ & Celupkan ke Tangki/ posisi awal \\
\hline
\end{tabular}

\section{Pengujian RTC}

Pengujian rangkaian rtc ds 3231 untuk menampilkan kalender tanggal, bulan, tahun dan waktu jam, menit, dan detik. Dengan memasukkan program ke sketch arduino, lalu di verifikasi jika tidak ada yang error langsung klik upload 
pada program hingga kalender dan waktu bias tampil di LCD 2 x 16 . Untuk seting jam dan tanggal hilangkan tanda // dahulu kemudian seting kalender dan jam, setelah di setting kembalikan lagi tanda //, maka waktu akan terbackup oleh modul.

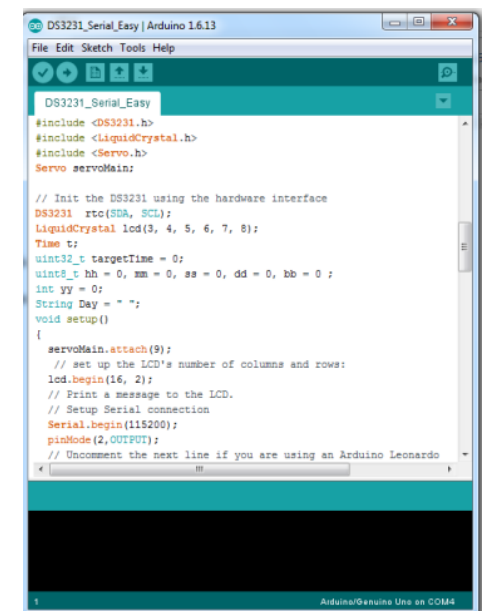

Gambar 4.1 Tampilan Program RTC ke Arduino

LCD 2 x 16 akan memberikan display inputan tanggal dan waktu sesuai setingan dan jika power sistem minimum dilepas maka waktu akan terback-up secara otomatis dengan daya dari baterai $3 \mathrm{~V}$.

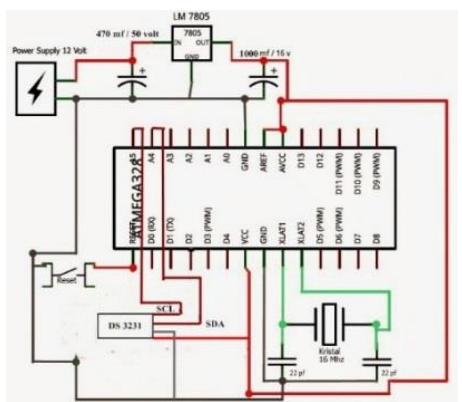

Gambar 4.2 Skema Rangkaian RTC ke ATmega 328

Tabel 4.2 Pengujian Hasil pengujian jam antara di Handphone dan di modul RTC

\begin{tabular}{|c|c|c|c|c|}
\hline $\begin{array}{l}\mathrm{N} \\
\mathrm{O}\end{array}$ & $\begin{array}{c}\text { Tangg } \\
\text { al }\end{array}$ & $\begin{array}{c}\text { Jam } \\
\text { di } \\
\text { HP }\end{array}$ & $\begin{array}{c}\text { Jam } \\
\text { di } \\
\text { Modu } \\
1\end{array}$ & $\begin{array}{c}\text { Selis } \\
\text { ih }\end{array}$ \\
\hline 1 & $\begin{array}{l}29-01 \\
-2017\end{array}$ & $\begin{array}{c}\text { 9:00: } \\
00 \\
\text { AM }\end{array}$ & $\begin{array}{l}9: 00: 0 \\
0 \text { AM }\end{array}$ & $\begin{array}{c}0 \\
\text { deti } \\
\mathrm{k}\end{array}$ \\
\hline 2 & $\begin{array}{l}29-01 \\
-2017\end{array}$ & $\begin{array}{c}1: 00: \\
00 \\
\text { PM }\end{array}$ & $\begin{array}{c}\text { 12:59: } \\
59 \\
\text { PM }\end{array}$ & $\begin{array}{c}1 \\
\text { deti } \\
k\end{array}$ \\
\hline 3 & $\begin{array}{l}29-01 \\
-2017\end{array}$ & $\begin{array}{c}5: 00: \\
00 \\
\text { PM }\end{array}$ & $\begin{array}{c}4: 59: 5 \\
8 \mathrm{PM}\end{array}$ & $\begin{array}{c}2 \\
\text { deti } \\
k\end{array}$ \\
\hline 4 & $\begin{array}{l}29-01 \\
-2017\end{array}$ & $\begin{array}{c}\text { 9:00: } \\
\text { 00 } \\
\text { PM }\end{array}$ & $\begin{array}{c}8: 59: 5 \\
8 \text { PM }\end{array}$ & $\begin{array}{c}2 \\
\text { deti } \\
k\end{array}$ \\
\hline 5 & $\begin{array}{l}30-01 \\
-2017\end{array}$ & $\begin{array}{c}1: 00: \\
00 \\
\text { AM }\end{array}$ & $\begin{array}{c}\text { 12:59: } \\
57 \\
\text { AM }\end{array}$ & $\begin{array}{c}3 \\
\text { deti } \\
k\end{array}$ \\
\hline 6 & $\begin{array}{l}30-01 \\
-2017\end{array}$ & $\begin{array}{c}\text { 5:00: } \\
00 \\
\text { AM }\end{array}$ & $\begin{array}{c}4: 59: 5 \\
5 \text { AM }\end{array}$ & $\begin{array}{c}5 \\
\text { deti } \\
k\end{array}$ \\
\hline 7 & $\begin{array}{l}30-01 \\
-2017\end{array}$ & $\begin{array}{c}\text { 9:00: } \\
00 \\
\text { AM }\end{array}$ & $\begin{array}{l}8: 59: 5 \\
4 \text { AM }\end{array}$ & $\begin{array}{c}6 \\
\text { deti } \\
k\end{array}$ \\
\hline 8 & $\begin{array}{l}30-01 \\
-2017\end{array}$ & $\begin{array}{c}\text { 1:00: } \\
00 \\
\text { AM }\end{array}$ & $\begin{array}{c}\text { 12:59: } \\
52 \\
\text { AM }\end{array}$ & $\begin{array}{c}8 \\
\text { deti } \\
k\end{array}$ \\
\hline 9 & $\begin{array}{l}30-01 \\
-2017\end{array}$ & $\begin{array}{c}\text { 5:00: } \\
00 \\
\text { AM }\end{array}$ & $\begin{array}{c}4: 59: 5 \\
0 \text { AM }\end{array}$ & $\begin{array}{c}10 \\
\text { deti } \\
\mathrm{k}\end{array}$ \\
\hline $\begin{array}{l}1 \\
0\end{array}$ & $\begin{array}{l}30-01 \\
-2017\end{array}$ & $\begin{array}{c}9: 00: \\
00 \\
\text { AM }\end{array}$ & $\begin{array}{l}8: 59: 4 \\
7 \mathrm{AM}\end{array}$ & $\begin{array}{c}13 \\
\text { deti } \\
k\end{array}$ \\
\hline
\end{tabular}

Berdasarkan tabel 4.2 diambil sampel sebanyak 10 percobaan dengan menggunakan perbedaan jam di handphone dan jam pada modul RTC 
DS 3231 selama 4 jam sekali, didapat hasil pengukuran seperti pada tabel 4.3 sehingga hasil perubahahan jam di modul cenderung melambat antara 1 - 13 detik tergantung lama penggunaan modul tersebut, dengan demikian modul ini cocok untuk aplikasi kritis yang sensitif terhadap akurasi waktu yang tidak perlu disinkronisasikan secara teratur terhadap jam eksternal.

\section{Pengujian sensor pH}

Sebelum tahap pengujian dilakukan untuk memastikan cairan $\mathrm{pH}$ buffer yang di gunakan sesuai dengan angka nominal yang ada, maka saya membandingkan dengan $\mathrm{pH}$ tester digital dengan merek $\mathrm{pH} 47$

Tabel 4.3 Tabel Hasil Pengujian PH Buffer dengan PH Tester Digital

\begin{tabular}{|c|c|c|c|c|}
\hline No & $\begin{array}{c}\text { PH } \\
\text { buffer }\end{array}$ & \multicolumn{2}{|c|}{$\begin{array}{c}\text { PH } \\
\text { tester } \\
\text { digital }\end{array}$} & $\begin{array}{c}\text { PH } \\
\text { lakmus }\end{array}$ \\
\hline \hline 1 & 4.00 & 4.0 & 4.1 & 4 \\
\hline 2 & 6.86 & 6.9 & 7.0 & 7 \\
\hline 3 & 9.18 & 9.1 & 9.2 & 9 \\
\hline
\end{tabular}

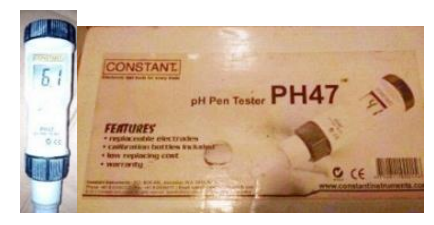

Gambar 4.3 PH Tester Digital PH47

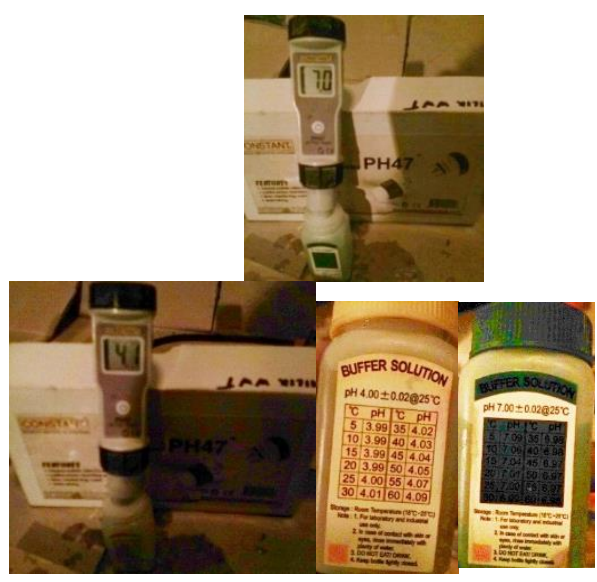

Gambar 4.4 Pengujian PH Tester dengan Cairan PH 4.00 Warna Kuning dan PH 7.00 Warna Hijau

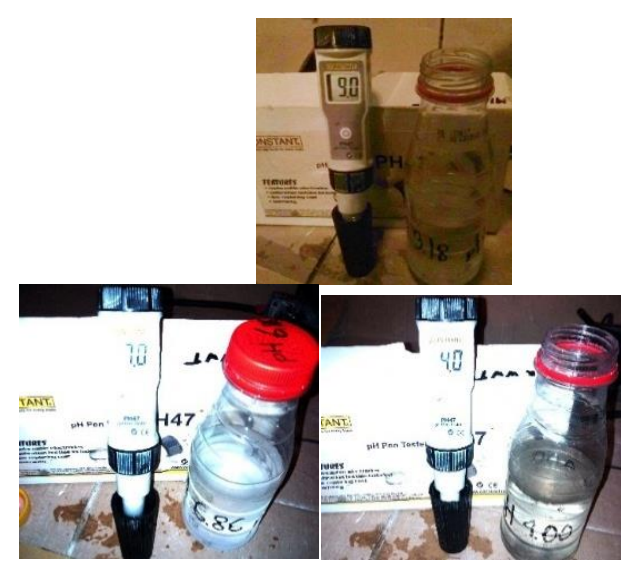

Gambar 4.5 Pengujian PH Buffer dengan Alat PH Tester

Pengujian sensor derajat keasaman $(\mathrm{pH})$ dilakukan untuk mengetahui nilai kondisi derajat keasaman $(\mathrm{pH})$ yang dihasilkan pada hasil pengukuran. Pengujian dilakukan dengan mengukur nilai ADC pada sensor $\mathrm{pH}$ serta hasil konversi nilai $\mathrm{ADC}$ ke $\mathrm{pH}$. Hasil konversi tersbut akan dibandingkan dengan bahan uji yang telah memiliki nilai $\mathrm{pH}$ tetap yaitu $\mathrm{pH} 9,18, \mathrm{pH} 6.86$, dan $\mathrm{pH} 4,00$. 
Tabel 4.4 Pengujian dengan menggunakan PH Buffer PH 4,00

\begin{tabular}{|c|c|c|c|}
\hline $\begin{array}{c}\mathrm{N} \\
\mathrm{o}\end{array}$ & $\begin{array}{c}\mathrm{pH} \\
\text { asli }\end{array}$ & $\begin{array}{c}\mathrm{pH} \\
\text { pengukura } \\
\mathrm{n}\end{array}$ & Selisih \\
\hline \hline 1 & $\begin{array}{c}4,0 \\
0\end{array}$ & 4,22 & 0,22 \\
\hline 2 & $\begin{array}{c}4,0 \\
0\end{array}$ & 4,20 & 0,20 \\
\hline 3 & $\begin{array}{c}4,0 \\
0\end{array}$ & 4,15 & 0,15 \\
\hline 4 & $\begin{array}{c}4,0 \\
0\end{array}$ & 4,12 & 0,12 \\
\hline 5 & $\begin{array}{c}4,0 \\
0\end{array}$ & 4,22 & 0,22 \\
\hline 6 & $\begin{array}{c}4,0 \\
0\end{array}$ & 4,10 & 0,10 \\
\hline 7 & $\begin{array}{c}4,0 \\
0\end{array}$ & 4,08 & 0,08 \\
\hline 8 & $\begin{array}{c}4,0 \\
0\end{array}$ & 4,10 & 0,10 \\
\hline 9 & $\begin{array}{c}4,0 \\
0\end{array}$ & 4,03 & 0,03 \\
\hline 10 & $\begin{array}{c}4,0 \\
0\end{array}$ & 4,06 & 0,06 \\
\hline
\end{tabular}

Berdasarkan tabel 4.4 diambil sampel sebanyak 10 percobaan dengan menggunakan buffer $\mathrm{pH} 4,00$, didapat hasil pengukuran seperti pada tabel 4.5 sehingga hasil selisih tersebut dimulai dari range $0,03-$ 0,22 . Hasil selisih tersebut menunjukkan nilai yang memiliki selisih nilai yang kecil sehingga antara nilai $\mathrm{pH}$ buffer dan $\mathrm{pH}$ pengukuran juga tidak jauh beda atau mendekati sama.
Tabel 4.5 Pengujian dengan menggunakan PH Buffer PH 6,86

\begin{tabular}{|c|c|c|c|}
\hline $\begin{array}{c}\mathrm{N} \\
\mathrm{o}\end{array}$ & $\mathrm{pH}$ asli & $\begin{array}{c}\mathrm{pH} \\
\text { pengukura } \\
\mathrm{n}\end{array}$ & $\begin{array}{c}\text { Selisi } \\
\mathrm{h}\end{array}$ \\
\hline \hline 1 & 6,86 & 6,96 & 0,10 \\
\hline 2 & 6,86 & 6,93 & 0,07 \\
\hline 3 & 6,86 & 6,95 & 0,09 \\
\hline 4 & 6,86 & 6,90 & 0,04 \\
\hline 5 & 6,86 & 6,90 & 0,04 \\
\hline 6 & 6,86 & 6,92 & 0,06 \\
\hline 7 & 6,86 & 6,93 & 0,07 \\
\hline 8 & 6,86 & 6,90 & 0,04 \\
\hline 9 & 6,86 & 6,89 & 0,03 \\
\hline 10 & 6,86 & 6,86 & 0 \\
\hline
\end{tabular}

Berdasarkan tabel 4.5 diambil sampel sebanyak 10 percobaan dengan menggunakan buffer $\mathrm{pH} 6,86$, dengan hasil selisih dimulai dari range $0-0,10$. Hasil selisih menunjukkan nilai selisih yang sangat kecil.

Tabel 4.6 Pengujian dengan menggunakan PH Buffer $\mathrm{PH}$ 9,18

\begin{tabular}{|c|c|c|c|}
\hline No & $\begin{array}{c}\mathrm{pH} \\
\text { asli }\end{array}$ & $\begin{array}{c}\mathrm{pH} \\
\text { pengukuran }\end{array}$ & Selisih \\
\hline \hline 1 & 9,18 & 9,87 & 0,69 \\
\hline 2 & 9,18 & 9,89 & 0,71 \\
\hline 3 & 9,18 & 9,07 & 0,11 \\
\hline 4 & 9,18 & 9,09 & 0,09 \\
\hline 5 & 9,18 & 9,11 & 0,07 \\
\hline
\end{tabular}




\begin{tabular}{|c|c|c|c|}
6 & 9,18 & 9,13 & 0,05 \\
\hline 7 & 9,18 & 9,14 & 0,04 \\
\hline 8 & 9,18 & 9,13 & 0,05 \\
\hline 9 & 9,18 & 9,11 & 0,07 \\
\hline 10 & 9,18 & 9,14 & 0,04 \\
\hline
\end{tabular}

Berdasarkan tabel 4.6 diambil sampel sebanyak 10 percobaan dengan menggunakan buffer $\mathrm{pH} 9,18$, didapat hasil pengukuran seperti pada tabel 4.6 sehingga hasil selisih tersebut dimulai dari range $0,04-$ 0,71,. Hasil selisih tersebut menunjukkan nilai yang memiliki selisih yang kecil sehingga antara nilai $\mathrm{pH}$ buffer dan $\mathrm{pH}$ pengukuran hampir sama.

\section{Pengujian alat keseluruhan}

Pengujian system pembersih otomatis sensor $\mathrm{pH}$ berbasis robot arm dilakukan pada jam 06.59.50 / waktu sebelum setingan jam untuk system pembersih sensor $\mathrm{pH}$ bergerak otomatis, Saat jam di LCD mulai pukul 07.00.00 robot arm bergerak naik, bergeser dan masuk ke cairan HCL selama 2 detik kemudian naik, bergeser lagi dan masuk ke botol kecil cairan $\mathrm{pH}$ netral / $\mathrm{pH} 7$ selama 3 detik lalu naik, bergeser lagi dan turun masuk ke tangki seperti awal.

Untuk pengujian stabilizer $\mathrm{pH}$ pada proses Treated Water dengan menggunakan cairan buffer dengan $\mathrm{pH}$ 4,00 dan 9,18, dengan cara memasukkan sensor $\mathrm{pH}$ kedalam cairan buffer dengan $\mathrm{pH} 9,18$
Tabel 4.7 Pengujian Keseluruhan

\begin{tabular}{|c|c|c|c|}
\hline $\begin{array}{c}\text { Waktu / } \\
\text { Jam }\end{array}$ & $\begin{array}{c}\text { Gerak Robot } \\
\text { Arm }\end{array}$ & $\mathrm{pH}$ & $\begin{array}{c}\text { Pompa } \\
\text { Soda }\end{array}$ \\
\hline 00.00 .00 & Berhenti & 0.00 & Start \\
\hline 01.00 .00 & Berhenti & 0.50 & Start \\
\hline 02.00 .00 & Berhenti & 1.00 & Start \\
\hline 03.00 .01 & Berhenti & 1.50 & Start \\
\hline 04.00 .00 & Berhenti & 2.00 & Start \\
\hline 05.00 .00 & Berhenti & 2.50 & Start \\
\hline 06.00 .00 & Berhenti & 3.00 & Start \\
\hline 07.00 .00 & Bergerak & 3.50 & Start \\
\hline 08.00 .00 & Berhenti & 4.00 & Start \\
\hline 09.00 .00 & Berhenti & 4.50 & Start \\
\hline 10.00 .00 & Berhenti & 5.00 & Start \\
\hline 11.00 .00 & Berhenti & 5.50 & Start \\
\hline 12.00 .00 & Berhenti & 6.00 & Start \\
\hline 13.00 .00 & Berhenti & 6.50 & Start \\
\hline 14.00 .00 & Berhenti & 7.00 & Stop \\
\hline 15.00 .00 & Bergerak & 7.50 & Stop \\
\hline 16.00 .00 & Berhenti & 8.00 & Stop \\
\hline 17.00 .00 & Berhenti & 8.50 & Stop \\
\hline 18.00 .00 & Berhenti & 9.00 & Stop \\
\hline 19.00 .00 & Berhenti & 9.50 & Stop \\
\hline 20.00 .00 & Berhenti & 10.00 & Stop \\
\hline 21.00 .00 & Berhenti & 10.50 & Stop \\
\hline 22.00 .00 & Berhenti & 11.00 & Stop \\
\hline 23.00 .00 & Bergerak & 11.50 & Stop \\
\hline
\end{tabular}

Pada tabel 4.7 dijelaskan bahwa pada waktu mulai pukul 00.00.00 - 23.00.00, robot ARM bergerak hanya pada jam 07.00.00, 15.00.00 dan 23.00.00 dan $\mathrm{pH}$ mulai 0.00 di $\mathrm{pH}$ asam - 11.50 pada $\mathrm{pH}$ basah, pompa soda akan start mulai pH 0.00 sampai pH 6.00 dan stop pada saat pH 7.00 sampai 11.50. 


\section{KESIMPULAN DAN SARAN}

\section{. Kesimpulan}

Berdasarkan hasil analisa dan pembahasan yang telah dilakukan, dapat di ambil beberapa kesimpulan yaitu sebagai berikut:

1. Berdasarkan hasil pengujian, alat dapat bekerja dengan baik motor pengaduk dan pompa sirkulasi dapat berputar dengan normal saat power masuk dan dapat di seting kecepatan motor pengaduknya dengan menggunakan potensiometer, layar LCD menampilkan tanggal, jam dan $\mathrm{pH}$ sesuai dengan cairan $\mathrm{pH}$ buffer.

2. Pada pengujian sistem pembersih sensor $\mathrm{pH}$ otomatis berbasis robot arm mulai gerak dengan ketepatan waktu yang pas dan dapat memasukkan sensor $\mathrm{pH}$ kedalam setiap tangki dengan sempurna.

3. Pada pengujian pompa soda hasil ini sesuai dengan yang diinginkan perusahaan untuk stabilizer $\mathrm{pH}$ yang ada pada tangki. Motor pompa menyala saat $\mathrm{pH}<=6.00$ dan akan berhenti saat $\mathrm{pH}>=7,00$.

\subsection{Saran}

Perlu dilakukan analisa lebih lanjut pada sistem pembersih sensor $\mathrm{pH}$ otomatis berbasis robot arm untuk mendapatkan tempat saat membersihkan sensor $\mathrm{pH}$ di perusahaan, karena ini hanya simulasi saja dan jika di aplikasikan di perusahaan maka memerlukan ukuran tempat yang lebih besar dan gerak yang lebih luas untuk di aplikasikan dengan tangki sesungguhnya.

\section{DAFTAR PUSTAKA}

[1]. Asmadi dan Suharno. 2012.' Jurnal Vokasi

Kesehatan', eprints.ums.ac.id /27259/2/04._BAB_I.pdf.21Agu stus 2016

[2]. Bayu Gilang Purnomo.2013."Pengertian Pompa".http://purnama bgp.blogspot. co.id/2013/06/pengertianpompa.html. 21 Agustus 2016.

[3]. Djuandi,Feri. 2011. "Pengenalan Arduino".

http://tobuku.com/docs/ Arduino Pengenalan.pdf. 25 Agustus 2016.

[4]. Hantoko.2013.Ofsite Facility Plant.PT.Petro Jordan Abadi: Gresik.

[5]. Himam Haqiqi, Sohibul. 2008. PH Meter Elektroda. Makalah Fakultas Peternakan Universitas Brawijaya. Malang.

[6]. Muhammad Syahwil dan Andi.Panduan mudah simulasi dan praktek mikrokontroler arduino. Yogyakarta.

[7]. Nasichin.2013.Overview Plant.PT.Petro Jordan Abadi: Gresik.

[8]. Noorulil A, Bayu dan Ratna Adil. Rancang Bangun Model Mekanik Alat untuk Mengukur Kadar Keasaman Susu Cair Sari Buah dan Soft Drink. Jurnal Teknik Elektronika Politeknik Elektronika Negeri Surabaya.

[9]. Onny.2016.”Prinsip kerja PH Meter".http://artikelteknologi.com/prinsip-kerja -phmeter/. 28 Agustus 2016. 
[10]. Peraturan Menteri Kesehatan Republik Indonesia Nomor 492/MENKES/PER/ IV/2010. Persyaratan Kualitas Air Minum.

\section{RIWAYAT HIDUP PENELITI}

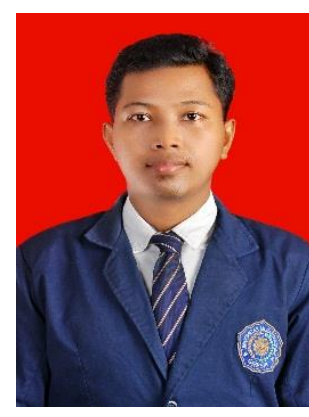

\section{CURRICULUM VITAE}
A. Biodata Pribadi
: Devit Nur
1. Nama Lengkap : Gresik, 01
2. Tempat / TglLahi Juni 1991
3. Jenis kelamin : Laki - laki

4. Kewarganegaraan : Indonesia

5. Tinggi / BeratBadan : $163 \mathrm{~cm} /$ $64 \mathrm{~kg}$

6. Agama : Islam

7. Status : Menikah

8. Alamat : JL Raya Meduran No.164 RT.002 RW.003 Roomo, Manyar, Gresik, Jawa Timur

9. No. Telp :0857-45663602

10. Email devitumg@yahoo.com

B. Riwayat Pendidikan

1. TK : TK.

Darmawanita, Gresik 1996-1998

2. $\mathrm{SD}$ : SDN Roomo 1998-2004

3. SMP : SMP N 1 Manyar 2004-2007

4. SMK : SMK PGRI 1 Gresik 2007-2010

5. PerguruanTinggi : Universitas Muhammadiyah Gresik, Program Studi Teknik Elektro 20112016 